\title{
A New Species of Extinct Parrot (Psittacidae: Eclectus) from Tonga and Vanuatu, South Pacific ${ }^{1}$
}

\author{
David W. Steadman ${ }^{2}$
}

\begin{abstract}
A new extinct species of parrot, Eclectus infectus Steadman, is described from 21 bones from archaeological (late Holocene) and paleontological (late Pleistocene) sites on three islands in the Kingdom of Tonga, with limited referred material (ulna, tibiotarsus) from a late Holocene archaeological site on Malakula, Vanuatu. Probably, therefore, the range of E. infectus also included at least the intervening island group of Fiji. The extinction of $E$. infectus occurred since the arrival of people in this region ca. 3,000 yr ago and presumably was due to human impact. A single, very fragmentary parrot tibiotarsus from Rota (Mariana Islands) may pertain to an indeterminate species of Eclectus. The only extant species of Eclectus is E. roratus, which occurs from the Solomon Islands westward to the Moluccas. Eclectus infectus provides the first evidence of the genus east of the Solomon Islands, although its biogeographic implications are not unique. Within Oceania (outside New Zealand and the Hawaiian Islands), human activities have eliminated the easternmost species in at least 17 other genera of land birds.
\end{abstract}

Parrots (order Psittaciformes, family Psittacidae sensu lato) have a substantial late Quaternary fossil record on tropical islands that includes many extinct species and populations. In the West Indies, for example, such losses have involved all three indigenous genera (Ara, Aratinga, and Amazona [Williams and Steadman 2001]). Fossils also have documented considerable late Quaternary losses of parrots on Pacific islands, especially in three genera, Vini, Cacatua, and Eclectus (Steadman in press). Here I describe a new species of Eclectus and discuss its biogeographic implications.

${ }^{1}$ Financial support came from the National Science Foundation (grants BSR-8607535, EAR-9714819, DEB0228682 ) and National Geographic Society (grant 512393). Manuscript accepted 21 December 2004.

${ }^{2}$ Florida Museum of Natural History, University of Florida, P.O. Box 117800, Gainesville, Florida 326117800 (phone: 352-392-1721 x465; fax: 352-846-0287; e-mail: dws@flmnh.ufl.edu).

Pacific Science (2006), vol. 60, no. 1:137-145

(C) 2006 by University of Hawai'i Press

All rights reserved

\section{MATERIALS AND METHODS}

The prehistoric parrot bones from sites in the Kindom of Tonga were obtained from vertically controlled excavations by sieving sediment through screens of 3.2- or $1.6-\mathrm{mm}$ mesh. The stratigraphic, chronologic, and cultural details of the Tongan sites are explained in Steadman (1993), Burley (1999), Dickinson et al. (1999), and Steadman et al. $(2002 a, b)$. The Malua Bay archaeological site on Malakula, Vanuatu, is described in Bedford et al. (1998). Steadman $(1992,1999)$ described the bone deposit at Payapai Cave on Rota, Mariana Islands.

The prehistoric specimens of Eclectus are cataloged in the Division of Ornithology, Florida Museum of Natural History, University of Florida (UF). Multiple five-digit catalog numbers for a single specimen, such as UF 52069/52076 for the holotypical femur, are for bone fragments originally cataloged separately but found to fit together with further research. Modern comparative skeletons are from the American Museum of Natural History (AMNH), UF, the National Museum of Natural History, Smithsonian Institution 
(USNM), and the University of Washington Burke Museum (чwвм). Osteological nomenclature generally follows Baumel et al. (1993).

The following modern skeletons were examined: Cacatua ducorpsi uf 39463, 39446, 39513; C. galerita galerita uf 25728; C. ophthalmica AMNH 332597; C. (Eolophus) roseicapilla UF 25735; Callocephalon fimbriatum UF 25737; Calyptorbynchus funereus uF 25729; Probosciger aterrimus uf 25679; Vini australis UF 25591; $V$. kublii USNM 498417; $V$. solitarius USNm 277040, 277322; Charmosyna papou UF 39659, ишвм 43041; C. pulchella UF 40403; Trichoglossus baematodus uF 39561; Lorius chlorocercus Uf 39487; Chalcopsitta cardinalis UF 39410, 39464; Eos bornea UF 18437; Pseudeos fuscata UF 25577; Eclectus $r$. roratus (female, male) UsNm 557136, 557137; Eclectus r. solomonensis (2 males) UF 39525, 40175; Eclectus roratus [captive] (3 females, 5 males, 2 ?) UF 25936-25941, USNM 346723, 430501, 490124, 557942; Geoffroyus geoffroyi USNM 560810; Prosopeia tabuensis uf 26179, 26180, 40741, 40743; Cyanoramphus auriceps uf 25961; C. $n$. novaehollaniae UF 25958; Eunymphicus cornutus uF 42707; and Micropsitta finschii uf 39450, 39459 .

\section{COMPARATIVE OSTEOLOGY AND SYSTEMATICS}

I compared the fossils from Tonga and Vanuatu with modern skeletal specimens representing most genera of cockatoos, lories, and parrots from Australia, New Guinea, and Indonesia and all genera from Oceania (see Materials and Methods), including especially the four genera that still occur in Polynesia (Vini, Charmosyna, Prosopeia, and Cyanoramphus). The fossil specimens are referred to Eclectus because of the following unique combination of characters.

Quadrate: base of processus orbitus concave; dorsal surface of condylus caudalis bulbous and medially oriented; concavity of lateral surface of condylus caudalis extends posteriad to processus zygomaticus.

Mandible: symphysis relatively flat, shallow, and wide, with rugose (not smooth) ventral surface texture; smooth medial outline of symphysis and ramus in ventral aspect.
Sternum: distal tip of spina externa blunt and not strongly bifurcated; lateral surfaces of spina externa partitioned by a muscle scar; in lateral aspect, overall anterior margin of spina externa convex rather than concave; dorsal surface of spina externa with proximomedial foramen; sulcus medianus sterni very pneumatic.

Coracoid: medial half of facies articularis sternalis gradually widens in a gentle arc.

Humerus: crista deltopectoralis originates nearly even with crista bicipitalis; fossa musculo brachialis shallow; attachment of anterior articular ligament elongate; tuberculum supracondylare ventrale large; sulcus humerotricipitalis deep.

Ulna: minimal curvature of proximal half of shaft in medial or lateral aspect; cross section of midshaft more angular (less circular); olecranon relatively large and distinctly offset by a deep sulcus tendineus; papillae remigiales caudales relatively indistinct; in ventral aspect, caudal margin of impressio brachialis relatively gently curved.

Radius: minimal curvature of proximal one-quarter of shaft; margo interosseus very distinct; sulcus tendineus consistently concave; sulcus ligamentum not deeply excavated.

Carpometacarpus: proximal intermetacarpal symphysis wide; fovea carpalis caudalis shallow.

Femur: in proximal aspect, facies articularis antitrochanterica relatively deep, resulting in little constriction at attachment of facies articularis acetabularis; linea intermuscularis cranialis avoids lateral margin of shaft but originates on medial margin of crista trochanteris; condylus medialis reaches its most proximal point near bone's midline rather than near epicondylus medialis; axis of condylus medialis oriented diagonally rather than parallel to axis of shaft; tuberculum musculo gastrocnemialis lateralis located relatively distal.

Tibiotarsus: extending from the distal extent of crista cnemialis cranialis, the anterior surface of the shaft is rather steeply raised diagonally, rather than gently rounded, to at least the midpoint of crista fibularis; in lateral aspect, crista fibularis thickens toward the distal end; in cranial aspect, shaft only slightly constricted above crista fibularis. 
Tarsometatarsus: shaft stout; sulcus extensorius long; fossa metatarsi I located at base of trochlea metatarsi II (rather than more proximal); trochlea metatarsi II medially expanded.

Eclectus infectus Steadman, n. sp.

Figures 1-3

HOLOTYPe: UF 52069/52076, complete femur, Unit S6W2, Layer II, Level 15, 'Anatu, 'Eua, Tonga. Collected by D. W. Steadman, T. W. Stafford Jr., and J. G. Stull on $25 \mathrm{No}-$ vember 1989 (Figure 1).

paratypes: 'Anatu, 'Eua, Tonga: uf 50652/50653 sternum, uf 52117 radius (Lay- er I); uf 52003/52075 ulna, uf 52060/52062/ 52073 radius, uf 50608 tibiotarsus (Layer II); UF 52784 sternum, UF 52057, 52549, 52900 three radii (Layer III). Tongoleleka Site, Lifuka, Tonga (various strata): uf 58284 quadrate, uf 57920 mandible, uf 58294 coracoid, UF 58063, 58300 two humeri, uf 58548/ 58549 carpometacarpus, uf 58512 tarsometatarsus, uf 58518,58519 pedal phalanges. Vaipuna Site, 'Uiha, Tonga: uf 58850 pedal phalanx (Unit 7, Level 9). Malua Bay archaeological site, Malakula, Vanuatu: Uf 61449 ulna, uf 61450 tibiotarsus.

DiAgnosis: A species of Eclectus that differs from the only known congeneric species,

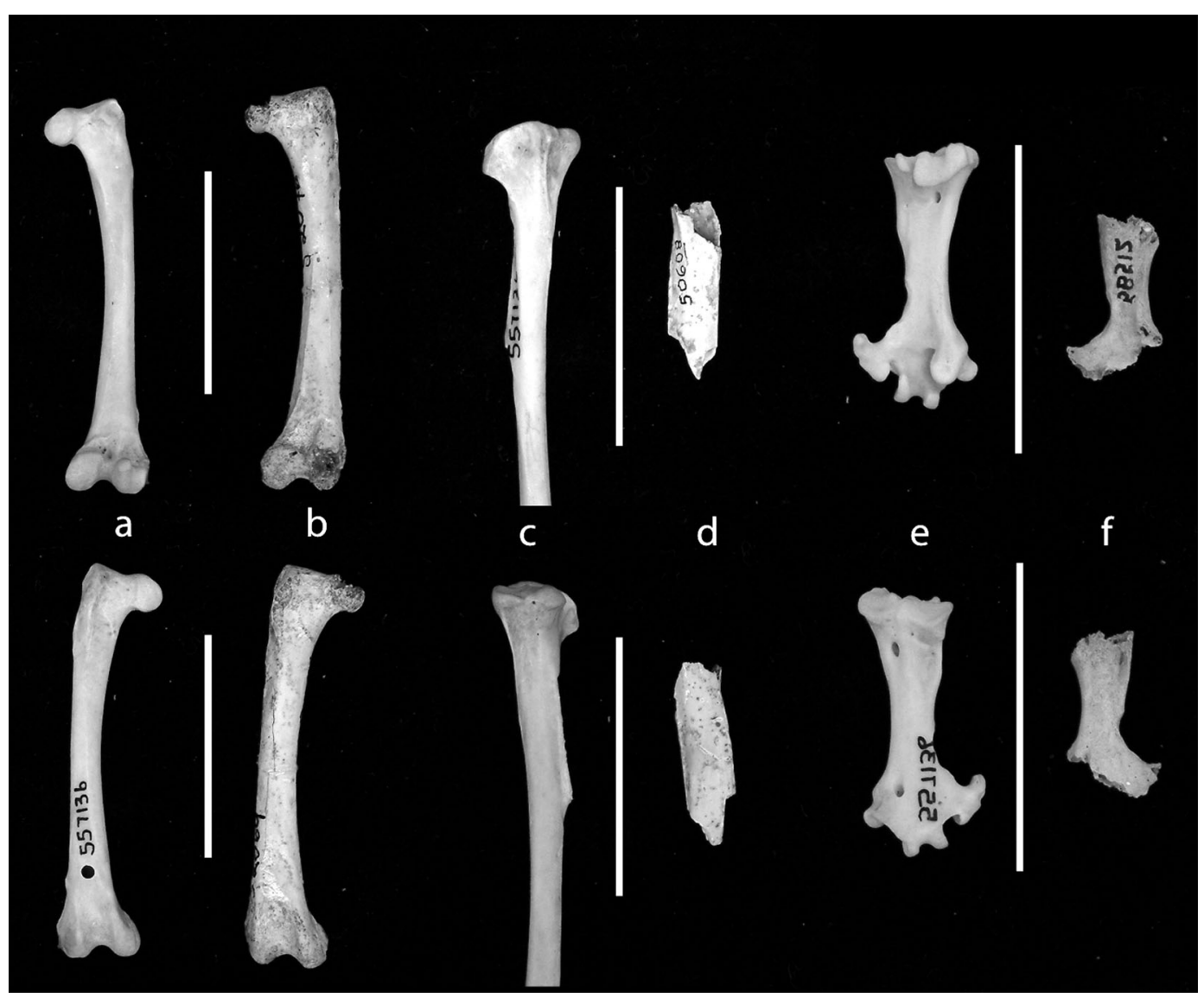

Figure 1. Eclectus. $a, b$, Femur in ventral (above) and dorsal (below) aspects. $c$, $d$, Tibiotarsus in dorsal (above) and ventral (below) aspects. $e, f$, Tarsometatarsus in plantar (above) and acrotarsial (below) aspects. $a, c, e$, E. roratus roratus, USNM 557136. $b, d, f$, E. infectus, n. sp., uf 52069/52076, 50608, 58512. Scale bars $=30 \mathrm{~mm}$. 
TABLE 1

Measurements (in mm) of Skeletal Elements in Eclectus, with Range and Sample Size (if $>1$ )

\begin{tabular}{|c|c|c|c|c|c|}
\hline Skeletal Element Parameter & $\begin{array}{c}\text { E. infectus, } \\
\text { n. sp., } \\
\text { Tonga: } \\
\text { 'Eua, } \\
\text { Lifuka }\end{array}$ & $\begin{array}{c}\text { E. cf. } \\
\text { infectus, } \\
\text { n. sp., } \\
\text { Vanuatu: } \\
\text { Malakula }\end{array}$ & $\begin{array}{c}\text { E. roratus } \\
\text { solomonensis, } \\
\text { Solomons: } \\
\text { Isabel }\end{array}$ & $\begin{array}{c}\text { E. roratus } \\
\text { roratus, } \\
\text { Moluccas: } \\
\text { Ternate, } \\
\text { Tobelo }\end{array}$ & $\begin{array}{c}\text { E. roratus } \\
\text { subsp.? } \\
\text { Captive }\end{array}$ \\
\hline \multicolumn{6}{|l|}{ Quadrate } \\
\hline Total height & 15.9 & - & $\begin{array}{l}14.0-14.2 \\
2\end{array}$ & 15.6 & $\begin{array}{l}13.7-14.2 \\
2\end{array}$ \\
\hline Minimum width of processus oticus & 2.3 & - & $1.9-2.2$ & 1.8 & $1.8-1.9$ \\
\hline Minimum depth of processus oticus & 2.2 & - & $\begin{array}{l}1.8-1.9 \\
2\end{array}$ & 1.7 & $\begin{array}{l}1.5-1.8 \\
2\end{array}$ \\
\hline $\begin{array}{l}\text { Combined width of capitulum } \\
\text { oticum and capitulum squamosum }\end{array}$ & 5.1 & - & $3.9-4.2$ & 4.5 & 4.1 \\
\hline \multicolumn{6}{|l|}{ Mandible } \\
\hline Depth at symphysis & 2.9 & - & $\begin{array}{l}2.5-2.8 \\
2\end{array}$ & 2.8 & $\begin{array}{l}2.7 \\
2\end{array}$ \\
\hline Shortest oblique length of dentary & 13.1 & - & $\begin{array}{c}10.2-10.3 \\
2\end{array}$ & 11.2 & $\begin{array}{c}11.1-11.4 \\
2\end{array}$ \\
\hline \multicolumn{6}{|l|}{ Sternum } \\
\hline Width of pila carinae & 3.2 & - & $\begin{array}{l}3.0-3.1 \\
2\end{array}$ & $\begin{array}{l}2.9-3.2 \\
2\end{array}$ & $\begin{array}{l}2.9-3.4 \\
8\end{array}$ \\
\hline Length of spina externae & $7.6+$ & - & $\begin{array}{l}6.9-7.5 \\
2\end{array}$ & $\begin{array}{l}7.4-8.5 \\
2\end{array}$ & $\begin{array}{l}7.0-8.0 \\
8\end{array}$ \\
\hline \multicolumn{6}{|l|}{ Humerus } \\
\hline Midshaft width & $\begin{array}{l}5.1-5.2 \\
2\end{array}$ & - & $\begin{array}{l}5.7-5.8 \\
2\end{array}$ & 6.1 & $\begin{array}{l}5.8-5.9 \\
2\end{array}$ \\
\hline Midshaft depth & $\begin{array}{l}4.4-4.5 \\
2\end{array}$ & - & $\begin{array}{l}4.8-4.9 \\
2\end{array}$ & 5.2 & $\begin{array}{l}4.5-5.1 \\
3\end{array}$ \\
\hline Distal width & 11.8 & - & $11.9-12.0$ & 12.7 & $\begin{array}{c}11.3-12.8 \\
3\end{array}$ \\
\hline \multicolumn{6}{|l|}{ Ulna } \\
\hline Proximal depth & 7.7 & - & $\begin{array}{l}6.6-6.9 \\
2\end{array}$ & $\begin{array}{l}6.7-7.7 \\
2\end{array}$ & $\begin{array}{l}6.8-7.7 \\
6\end{array}$ \\
\hline Proximal width & 9.1 & - & $\begin{array}{l}8.3 \\
2\end{array}$ & $\begin{array}{l}9.0-10.5 \\
2\end{array}$ & $\begin{array}{l}9.0-9.5 \\
6\end{array}$ \\
\hline Least width of shaft & 3.9 & 4.0 & $\begin{array}{l}3.3-3.4 \\
2\end{array}$ & $\begin{array}{l}4.0-4.4 \\
2\end{array}$ & $\begin{array}{l}3.6-4.4 \\
6\end{array}$ \\
\hline Least depth of shaft & 4.8 & 4.7 & $\begin{array}{l}3.9-4.1 \\
2\end{array}$ & $\begin{array}{l}4.4-5.0 \\
2\end{array}$ & $\begin{array}{l}4.0-4.7 \\
6\end{array}$ \\
\hline \multicolumn{6}{|l|}{ Radius } \\
\hline Total length & 73.4 & - & $\begin{array}{l}66.5-68.4 \\
2\end{array}$ & $\begin{array}{c}68.5-75.4 \\
2\end{array}$ & $\begin{array}{c}67.8-74.4 \\
6\end{array}$ \\
\hline Proximal width & $\begin{array}{l}4.0-4.2 \\
3\end{array}$ & - & $\begin{array}{l}3.2 \\
2\end{array}$ & $\begin{array}{l}3.8-3.9 \\
2\end{array}$ & $\begin{array}{l}3.1-3.8 \\
6\end{array}$ \\
\hline Proximal depth & $\begin{array}{l}4.6-5.2 \\
3\end{array}$ & - & $\begin{array}{l}3.9-4.0 \\
2\end{array}$ & $\begin{array}{l}4.6-5.2 \\
2\end{array}$ & $\begin{array}{l}4.3-4.9 \\
6\end{array}$ \\
\hline Least width of shaft & 2.4 & - & $2^{1.9-2.0}$ & $\begin{array}{l}2.2-2.4 \\
2\end{array}$ & $\begin{array}{l}1.9-2.6 \\
6\end{array}$ \\
\hline Least depth of shaft & 2.2 & - & $2^{1.6-1.8}$ & $\begin{array}{l}2.0-2.3 \\
2\end{array}$ & $\begin{array}{l}1.7-2.1 \\
6\end{array}$ \\
\hline Distal width & 6.8 & - & $\begin{array}{l}6.0-6.4 \\
2\end{array}$ & $\begin{array}{l}6.6-7.2 \\
2\end{array}$ & $\begin{array}{l}6.0-6.7 \\
6\end{array}$ \\
\hline
\end{tabular}


TABLE 1 (continued)

\begin{tabular}{|c|c|c|c|c|c|}
\hline Skeletal Element Parameter & $\begin{array}{c}\text { E. infectus, } \\
\text { n. sp., } \\
\text { Tonga: } \\
\text { 'Eua, } \\
\text { Lifuka }\end{array}$ & $\begin{array}{c}\text { E. cf. } \\
\text { infectus, } \\
\text { n. sp., } \\
\text { Vanuatu: } \\
\text { Malakula }\end{array}$ & $\begin{array}{l}\text { E. roratus } \\
\text { solomonensis, } \\
\text { Solomons: } \\
\text { Isabel }\end{array}$ & $\begin{array}{l}\text { E. roratus } \\
\text { roratus, } \\
\text { Moluccas: } \\
\text { Ternate, } \\
\text { Tobelo }\end{array}$ & $\begin{array}{l}\text { E. roratus } \\
\text { subsp.? } \\
\text { Captive }\end{array}$ \\
\hline \multicolumn{6}{|l|}{ Femur } \\
\hline Total length & 51.3 & - & $\begin{array}{l}43.8-45.5 \\
2\end{array}$ & $\begin{array}{l}46.3-49.8 \\
2\end{array}$ & $\begin{array}{l}44.2-49.2 \\
5\end{array}$ \\
\hline Midshaft width & 4.7 & - & $\begin{array}{l}3.2-3.4 \\
2\end{array}$ & $\begin{array}{l}3.6-3.9 \\
2\end{array}$ & $\begin{array}{l}3.4-4.4 \\
5\end{array}$ \\
\hline Midshaft depth & 5.4 & - & $\begin{array}{l}3.4-3.6 \\
2\end{array}$ & $\begin{array}{l}4.1-4.2 \\
2\end{array}$ & $\begin{array}{l}3.8-4.4 \\
5\end{array}$ \\
\hline Depth of head & 5.4 & - & $\begin{array}{l}4.4-4.5 \\
2\end{array}$ & $\begin{array}{l}4.5-5.2 \\
2\end{array}$ & $\begin{array}{l}4.5-5.3 \\
5\end{array}$ \\
\hline Depth of medialis condylus & 7.6 & - & $\begin{array}{l}5.6-5.7 \\
2\end{array}$ & $\begin{array}{l}6.6-6.8 \\
2\end{array}$ & $\begin{array}{l}6.0-6.5 \\
5\end{array}$ \\
\hline \multicolumn{6}{|l|}{ Tibiotarsus } \\
\hline Width at midpoint of crista fibularis & 5.9 & 5.7 & $\begin{array}{l}4.0-4.1 \\
2\end{array}$ & $\begin{array}{l}4.4-4.8 \\
2\end{array}$ & $\begin{array}{l}4.3-5.0 \\
5\end{array}$ \\
\hline Depth at midpoint of crista fibularis & 3.6 & 4.1 & $\begin{array}{l}3.1-3.2 \\
2\end{array}$ & $\begin{array}{l}3.5-3.6 \\
2\end{array}$ & $\begin{array}{l}3.2-3.5 \\
5\end{array}$ \\
\hline $\begin{array}{l}\text { Tarsometatarsus } \\
\text { Least width of shaft }\end{array}$ & 3.9 & - & $\begin{array}{l}3.9-4.1 \\
2\end{array}$ & 4.0 & 3.8 \\
\hline
\end{tabular}

E. roratus, in its generally larger, more robust cranial and leg elements (Table 1) and in the following characters: quadrate (Figure 2) with capitulum oticus and capitulum squamosus fused; mandible (Figure 2) with ventral surfaces of symphysis less rounded in both posterior and lateral aspects; humerus (Figure 3) with deeper ventral portion of fossa musculo brachialis; ulna (Figure 3) with less protrudent tuberculum ligamentum collateralis ventralis and processus cotylaris dorsalis; radius (Figure 3) with sulcus tendinosus extending to make a concave outline of facies articularis radiocarpalis, and cotyla humeralis more circular (less ovoid) in proximal aspect; femur (Figure 1) with stouter shaft, and with condylus medialis on same plane as shaft in medial aspect; tibiotarsus (Figure 1) with more prominent intermuscular line on medial margin of shaft, opposite crista fibularis; tarsometatarsus (Figure 1) with more prominent fossa metatarsi I.

eтYMology: From the Latin infectus meaning "dyed, stained, tainted" (Brown 1956:438) in reference to the presumedly brightly colored plumage of this extinct parrot. The living Eclectus roratus is very brightly colored and unique among all birds in having the male plumage mainly green and the female plumage mainly red.

REMARKS: Eclectus infectus had proportionately slightly smaller wings than in E. roratus. This conforms to a general (though poorly documented) trend that volant land birds from remote Pacific islands have proportionately smaller wings than congeneric relatives from New Guinea, the Bismarcks, or the Solomons (J. Sailer, D.W.S., pers. obs.). I note that one tarsometatarsus of $E$. infectus from Lifuka (Uf 58512 [Figure 3]) is nearly identical in size to that of modern E. roratus, unlike other leg elements that are larger in the extinct species.

The evidence that Eclectus infectus inhabited Vanuatu is limited to two specimens from Malakula that are similar in size to the Tongan specimens. The ulna (UF 61449) is a 3.5 -cm-long portion of the shaft that agrees with Eclectus in having a cross section of the midshaft that is more angular (less circular) 


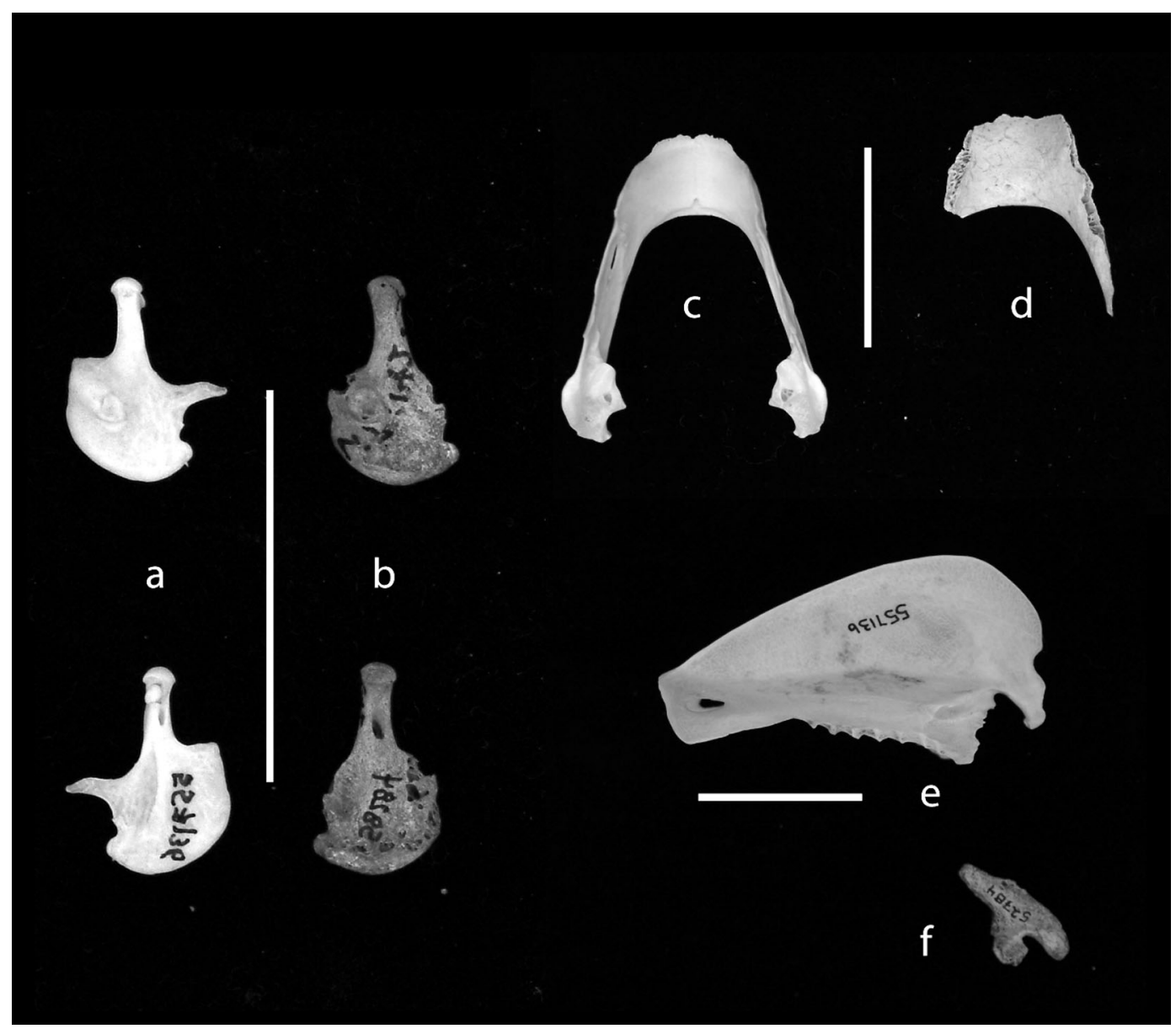

Figure 2. Eclectus. $a, b$, Quadrate in lateral (above) and medial (below) aspects. $c$, d, Mandible in dorsal aspect. $e, f$, Sternum in lateral aspect. $a, c, e$, E. roratus roratus, usnm 557136. $b, d, f$, E. infectus, n. sp., uf 58284, 57920. Scale bars $=30 \mathrm{~mm}$.

than in other Oceanic genera. The tibiotarsus (UF 61450) is a 2.5 -cm-long section of shaft (including crista fibularis) that agrees with Eclectus in having the anterior surface of the shaft steeply raised diagonally (rather than gently rounded) to the midpoint of crista fibularis. Pending discovery of more material, my referral of the Vanuatu specimens to $E$. infectus is tentative.

A single tibiotarsal fragment (USNM 436602) from Payapai Cave, Rota, Mariana Islands, is very tentatively referred to Eclectus species indeterminate. This specimen, from a bone deposit ca. 1,000 yr old (Steadman
1992,1999 , in press), is too fragmentary for positive identification to genus but does indicate the former presence of a large parrot in the Marianas, an island group devoid of parrots in modern times.

\section{DISCUSSION}

I regard all living parrots as best classified in a single family (Psittacidae) defined by a number of unique morphological and other traits (Smith 1975), but many recent authors recognize the cockatoos (Cacatuinae) and lories (Loriinae) as separate families (Cacatuidae, 


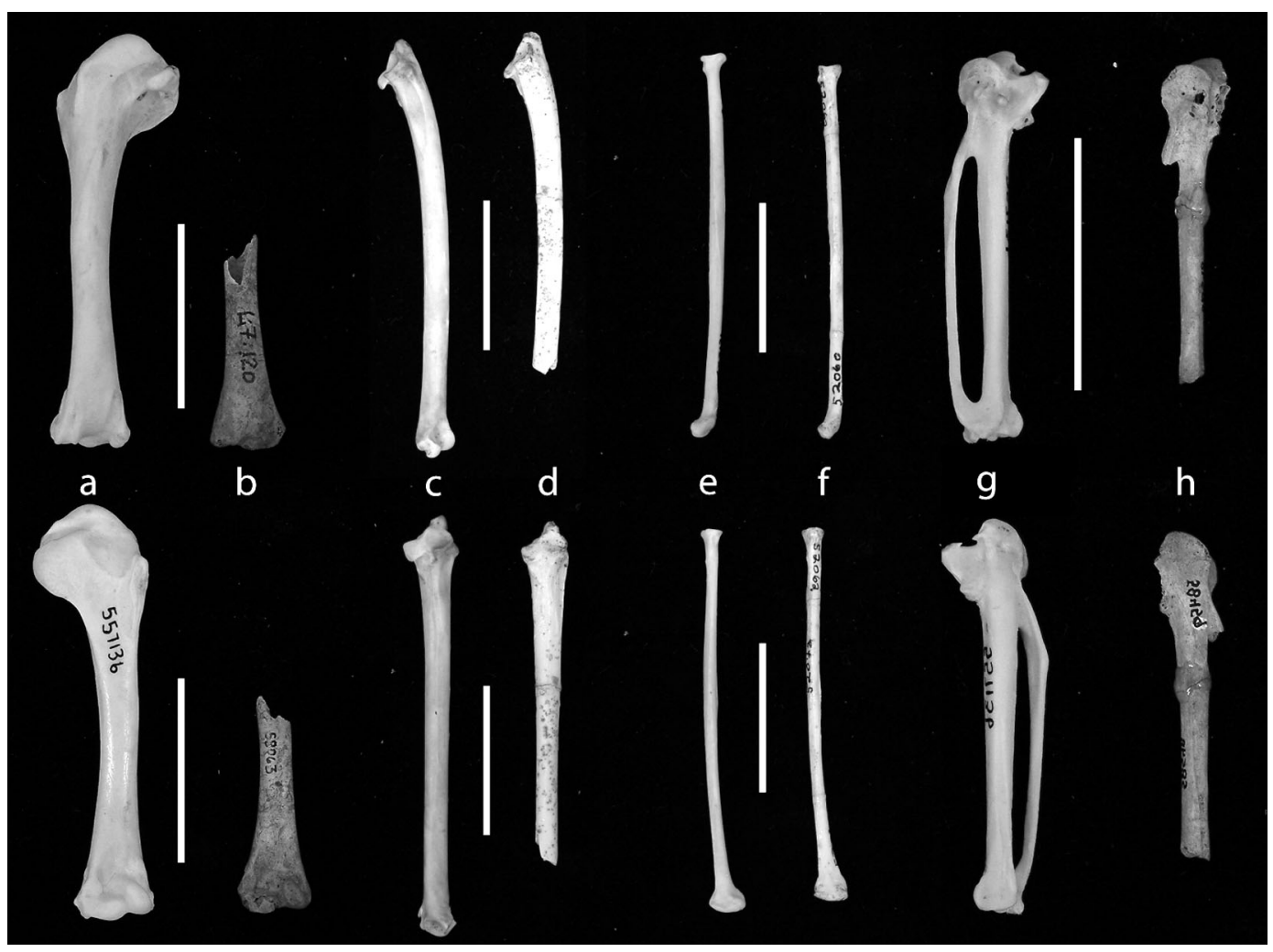

Figure 3. Eclectus. $a, b$, Humerus in caudal (above) and cranial (below) aspects. $c, d$, Ulna in ventral (above) and radial (below) aspects. $e, f$, Radius in dorsal (above) and ulnar (below) aspects. $g$, $h$, Carpometacarpus in ventral (above) and dorsal (below) aspects. $a, c, e, b$, E. roratus roratus, USNM 557136. b, d, f, g, E. infectus, n. sp., uf 58063, 52003/52075, 52060/ 52062/52073. Scale bars $=30 \mathrm{~mm}$.

Loriidae) from psittacine parrots (Sibley and Ahlquist 1990, Christidis et al. 1991, Boles 1993, Brown and Toft 1999). Whether these three groups are classified at the familial or subfamilial level, the order Psittaciformes as a whole is widely recognized as monophyletic. Among living genera of parrots, Eclectus may be most closely related to Geoffroyus as part of a poorly defined, possibly polyphyletic assemblage of psittacine parrots (Christidis et al. 1991) that may also include Psittacula, Psittinus, and Tanygnathus (Mayr and Göhlich 2004).

Although the Australian-Papuan-Oceanic region is the modern center of taxonomic diversity for parrots, the only Tertiary psittacid fossils there are of Cacatua sp. from the early to middle Miocene Riversleigh site, northwestern Queensland (Boles 1993). Late Quaternary parrot fossils, on the other hand, are phylogenetically and biogeographically important in providing evidence of many anthropogenically exterminated species and populations, especially in the genus Vini (Steadman and Zarriello 1987, Steadman in press). Of the 13 genera of parrots in tropical Oceania, seven are confined today to the Bismarcks and the Solomons. Two of these genera, Cacatua and Eclectus, occurred farther east in Oceania prehistorically (New Caledonia for Cacatua, Vanuatu and Tonga for Eclectus [Steadman in press, herein]).

Within Tonga, bones of Eclectus infectus have been found on three islands thus far. Es- 
pecially considering that two of these, Lifuka and 'Eua, have the most extensive fossil records of any Tongan island, it seems likely that $E$. infectus was widespread if not found throughout Tonga at first human contact. Eclectus roratus occurs from the Moluccas eastward through New Guinea, northernmost Australia, and the Bismarcks to the Solomon Islands (Mayr and Diamond 2001). As the late Quaternary fossil record of Oceania improves, I believe that a form of Eclectus will be discovered as well in the Santa Cruz Group, Rennell and Bellona, New Caledonia, and Fiji.

Two species of parrots are found in Tonga today. The first, Vini australis (Blue-crowned Lorikeet), is widespread in the Ha'apai Group but has been extirpated in historic times on most other Tongan islands (Steadman 1998, Steadman and Freifeld 1998). The second, Prosopeia tabuensis (Red Shining Parrot), is not native to Tonga, but was introduced from Fiji in late prehistoric times (Rinke 1989). Bones from prehistoric sites (both cultural and precultural) in Ha'apai and on 'Eua represent Vini australis, V. (Phigys) solitarius (Collared Lorikeet [confined today to Fiji]), and Eclectus infectus, raising the Tongan native parrot fauna from one to three species.

In Vanuatu today, Trichoglossus haematodus (Rainbow Lorikeet) is widespread and Charmosyna palmarum (Green Palm Lorikeet) occurs more locally (Bregulla 1992:189-192). Bones of both species have been found in archaeological contexts (Steadman in press). As in Tonga, Eclectus infectus increases the native parrot fauna of Vanuatu to three species.

Finally, Eclectus infectus provides another instance of prehistoric bones from a species of land bird, usually extinct, being discovered farther east in Oceania than the current range of any living congeneric species. Other examples are found in night-herons (Nycticorax), ospreys (Pandion), hawks (Accipiter), megapodes (Megapodius), rails (Gallirallus, Porzana, Porphyrio), columbids (Ducula, Macropygia, Caloenas, Gallicolumba), cockatoos (Cacatua), cuckoos (Cacomantis), owls (Ninox), hornbills (Aceros), swallows (Hirundo), and starlings (Aplonis) (Steadman 1988, 1993, 1995, 1997, in press, Balouet and Olson 1989). A similar situation has been found in certain skinks and geckos (Pregill 1993) and bats (Koopman and Steadman 1995), once again revealing how deceptive modern distributions of Oceanic vertebrates can be.

\section{ACKNOWLEDGMENTS}

For research permits and other assistance, I thank current and former officials of the Tongan Government, particularly Prime Minister 'Ulukalala Lavaka 'Ata, S. Faka'osi, S. F. Fotu, L. Muller, H. Palu, N. Prescott, and U. Samani. D. V. Burley, J. J. Kirchman, C. Matavalea, L. Matavalea, D. S. Pahlavan, G. K. Pregill, M. J. Reetz, S. Rohwer, S. Schaack, T. W. Stafford Jr., and J. G. Stull provided information or helped in the field or laboratory. The bones from Vanuatu were kindly provided by S. Bedford and $M$. Spriggs, whose research is permitted through R. Regenvanu of the Vanuatu National Museum and Cultural Center. I also thank the curatorial staffs at AMNH, BMNH, USNM, and UWBM for access to collections and other courtesies. The photographs are by J. J. Kirchman. A. W. Kratter and T. Webber kindly commented on the manuscript.

\section{Literature Cited}

Balouet, J., and S. L. Olson. 1989. Fossil birds from the late Quaternary deposits in New Caledonia. Smithson. Contrib. Zool. 469.

Baumel, J. J., A. S. King, A. M. Lukas, J. E. Breazile, and H. E. Evans, eds. 1993. Nomina anatomica avium. Academic Press, London.

Bedford, S., M. Spriggs, M. Wilson, and R. Regenvanu. 1998. The Australian National University-National Museum of Vanuatu Archaeological Project 1994-7: A preliminary report on the establishment of cultural sequences and rock art research. Asian Perspect. 37:165-193.

Boles, W. E. 1993. A new cockatoo (Psittaciformes: Cacatuidae) from the Tertiary of Riversleigh, northwestern Queensland, and an evaluation of rostral characters in the systematics of parrots. Ibis 135:8-18.

Bregulla, H. L. 1992. Birds of Vanuatu. An- 
thony Nelson, Shropshire, United Kingdom.

Brown, D. M., and C. A. Toft. 1999. Molecular systematics and biogeography of the cockatoos (Psittaciformes: Cacatuidae). Auk 116:141-157.

Brown, R. W. 1956. Composition of scientific words. Smithsonian Institution Press, Washington, D.C.

Burley, D. V. 1999. Lapita settlement to the east: New data and changing perspectives from Ha'apai (Tonga) prehistory. Pages 189-200 in J.-C. Galipaud and I. Lilley, eds. The Pacific from 5000 to 2000 BP. Éd. Inst. Recherche Dével., Paris, France.

Christidis, L., R. Schodde, D. D. Shaw, and S. F. Maynes. 1991. Relationships among the Australo-Papuan parrots, lorikeets, and cockatoos (Aves: Psittaciformes): Protein evidence. Condor 93:302-317.

Dickinson, W. R., D. V. Burley, and R. Shutler. 1999. Holocene paleoshoreline record in Tonga: Geomorphic features and archaeological implications. J. Coastal Res. 15:682-700.

Koopman, K. F., and D. W. Steadman. 1995. Extinction and biogeography of bats on 'Eua, Kingdom of Tonga. Am. Mus. Novit. 3125.

Mayr, E., and J. M. Diamond. 2001. Birds of northern Melanesia. Oxford University Press, Oxford, United Kingdom.

Mayr, G., and U. B. Göhlich. 2004. A new parrot from the Miocene of Germany, with comments on the variation of hypotarsus morphology in some Psittaciformes. Belg. J. Zool. 134:47-54.

Pregill, G. K. 1993. Fossil lizards from the Late Quaternary of 'Eua, Tonga. Pac. Sci. 47:101-114.

Rinke, D. 1989. The relationships and taxonomy of the Fijian parrot genus Prosopeia. Bull. Br. Ornithol. Club 109:185-195.

Sibley, C. G., and J. E. Ahlquist. 1990. Phylogeny and classification of birds. Yale University Press, New Haven, Connecticut.

Smith, G. A. 1975. Systematics of parrots. Ibis 117:18-68.

Steadman, D. W. 1988. A new species of Porphyrio (Aves: Rallidae) from archaeological sites in the Marquesas Islands. Proc. Biol. Soc. Wash. 101:162-170.

- 1992. Extinct and extirpated birds from Rota, Mariana Islands. Micronesica 25:71-84.

1993. The biogeography of Tongan birds before and after human impact. Proc. Natl. Acad. Sci. U.S.A. 90:818-822.

- 1995. Prehistoric extinctions of Pacific island birds: Biodiversity meets zooarchaeology. Science (Washington, D.C.) 267:1123-1131.

-. 1997. Historic biogeography and community ecology of Polynesian pigeons and doves. J. Biogeogr. 24:157-173.

. 1998. Status of land birds on selected islands in the Ha'apai Group, Kingdom of Tonga. Pac. Sci. 52:14-34.

- 1999. The prehistory of vertebrates, especially birds, on Tinian, Aguiguan, and Rota, Northern Mariana Islands. Micronesica 31:319-345.

- In press. The biogeography and extinction of tropical Pacific birds. University of Chicago Press, Chicago.

Steadman, D. W., and H. B. Freifeld. 1998. Distribution, relative abundance, and habitat relationships of landbirds in the Vava'u Group, Kingdom of Tonga. Condor 100:609-628.

Steadman, D. W., and M. C. Zarriello. 1987. Two new species of parrots (Aves: Psittacidae) from archaeological sites in the Marquesas Islands. Proc. Biol. Soc. Wash. 100:518-528.

Steadman, D. W., G. K. Pregill, and D. V. Burley. 2002a. Rapid prehistoric extinction of iguanas and megapodes in Polynesia. Proc. Natl. Acad. Sci. U.S.A. 99:36733677.

Steadman, D. W., A. Plourde, and D. V. Burley. 2002b. Prehistoric butchery and consumption of birds in the Kingdom of Tonga, South Pacific. J. Archaeol. Sci. 29:571-584.

Williams, M. I., and D. W. Steadman. 2001. The historic and prehistoric distribution of parrots (Psittacidae) in the West Indies. Pages 175-189 in C. A. Woods and F. E. Sergile, eds. Biogeography of the West Indies. CRC Press, Boca Raton, Florida. 
